\title{
CellTracker Green labelling vs. rose bengal staining: CTG wins by points in distinguishing living from dead anoxia-impacted copepods and nematodes
}

\author{
M. Grego ${ }^{1}$, M. Stachowitsch ${ }^{2}$, M. De Troch ${ }^{3}$, and B. Riedel ${ }^{2}$ \\ ${ }^{1}$ Marine Biology Station Piran, National Institute of Biology, Fornače 41, 6330 Piran, Slovenia \\ ${ }^{2}$ Department of Limnology and Oceanography, University of Vienna, Althanstrasse 14, 1090 Vienna, Austria \\ ${ }^{3}$ Marine Biology Section, Ghent University, Krijgslaan 281, Campus Sterre S8, 9000 Ghent, Belgium \\ Correspondence to: M. Grego (grego@mbss.org)
}

Received: 11 January 2013 - Published in Biogeosciences Discuss.: 18 February 2013

Revised: 13 May 2013 - Accepted: 28 May 2013 - Published: 9 July 2013

\begin{abstract}
Hypoxia and anoxia have become a key threat to shallow coastal seas. Much is known about their impact on macrofauna, less on meiofauna. In an attempt to shed more light on the latter group, in particular from a process-oriented view, we experimentally induced short-term anoxia (1 week) in the northern Adriatic Sea (Mediterranean) and examined the two most abundant meiofauna taxa - harpacticoid copepods and nematodes. Both taxa also represent different ends of the tolerance spectrum, with copepods being the most sensitive and nematodes among the most tolerant. We compared two methods: CellTracker Green (CTG) - new labelling approach for meiofauna - with the traditional rose bengal (RB) staining method. CTG binds to active enzymes and therefore colours live organisms only. The two methods show considerable differences in the number of living and dead individuals of both meiofauna taxa. Generally, RB will stain dead but not yet decomposed copepods and nematodes equally as it does live ones. Specifically, RB significantly overestimated the number of living copepods in all sediment layers in anoxic samples, but not in any normoxic samples. In contrast, for nematodes, the methods did not show such a clear difference between anoxia and normoxia. RB overestimated the number of living nematodes in the top sediment layer of normoxic samples, which implies an overestimation of the overall live nematofauna. For monitoring and biodiversity studies, the RB method might be sufficient, but for more precise quantification of community degradation, especially after an oxygen depletion event, CTG labelling is a better tool. Moreover, it clearly highlights the surviving species within
\end{abstract}

the copepod or nematode community. As already accepted for foraminiferal research, we demonstrate that the CTG labelling is also valid for other meiofauna groups.

\section{Introduction}

Detecting disturbance-induced changes in animal communities from a process-oriented perspective often requires shortterm experiments and accurate detection techniques. This is especially true in examining stress-sensitive species and community threshold dynamics/responses. Coastal hypoxia (low dissolved oxygen $\mathrm{DO}<2 \mathrm{mLL}^{-1}$; Diaz and Rosenberg, 2008) and anoxia have become recognized as a key emerging problem in the last decades, with an increasing number of affected sites coupled with increasing intensity, frequency and duration of events (Gooday et al., 2009; Rabalais et al., 2010; Zhang et al., 2010, see; also this issue and references therein). Adequate measurements to monitor the impacted fauna and identify sensitive and more tolerant species is therefore pivotal, especially when the course of oxygen decline is rapid, e.g. within several days to a week, as in the Adriatic Sea (Stachowitsch, 1984, 1991; Faganeli et al., 1985; Justić et al., 1993). While the mortality of macrofauna organisms can often be visually identified from changes in colour, behaviour and/or body shape of individuals (Riedel et al., 2012), the discrimination of dead from living meiofauna individuals requires more efficient methods and often a taxonomist's expertise. 
Beyond examining captured meiofauna organisms individually to see which are still moving or showing other signs of life (Steyaert et al., 2007), staining of freshly captured organisms is the traditional method used (Elefteriou and McIntyre, 2005). This is the only feasible method to distinguish between living and dead organisms in the abundant and numerous replicated samples necessary to answer specific ecological questions. Recently, however, a number of foraminiferal studies showed that the traditional rose bengal (RB) staining method (Walton, 1952) is often inadequate to distinguish with certainty living from dead organisms.

The RB staining method is commonly used in meiofauna studies (Thiel, 1966; Tiemann and Betz, 1979; Higgins and Thiel, 1988; Elefteriou and McIntyre, 2005; Giere, 2009). The RB is a typical bulk stain which adheres to (cytoplasmatic) proteins and is applied into formalin-fixed samples (Higgins and Thiel, 1988; Somerfield et al., 2005). As a stain it has various advantages (cheap, simple to apply, animals are easily visible under light microscope), but on the negative side it is a nonvital stain that stains proteins regardless if the cell/animal is dead or alive (Bernhard et al., 2006). It also colours different meiofauna organisms differently (Giere, 2009). Nonspecificity of RB stain explains the use of vital stains in foraminiferal studies (Bernhard et al., 1995, 2006; Bernhard, 2000; Pucci et al., 2009). The cytoplasm of Foraminifera stays in the shell for a long period after death, particularly in anoxic conditions, and it still stains well with RB (Bernhard et al., 1995, 2006; Bernhard, 2000; Pucci et al., 2009).

The present study is based on the paper from Bernhard et al. (2006), who compared CellTracker Green (CTG) labelling with rose bengal staining to distinguish live from dead benthic foraminifera. The principal idea behind the approach is to determine the most accurate method that exclusively labels surviving cells/organisms (Bernhard et al., 2006; Peperzak and Brussaard, 2011) in short-term disturbance studies such as hypoxia/anoxia experiments. When living cells are incubated with fluorogenic probes such as CTG, the probe passes through the cellular membrane and reaches the cytoplasm, where hydrolysis with nonspecific esterase causes the fluorogenic reaction (Bernhard et al., 2006; Pucci et al., 2009; Morigi and Geslin, 2009; Heinz and Geslin, 2012). Once in the cell, the CTG probe is converted to cell-impermeant reaction products (Peperzak and Brussaard, 2011). CTG is applied in many fields, such as medicine e.g. human tissue cultures (Boleti et al., 2000); parasitology e.g. drug-multicellular parasites relation (TrejoChávez et al., 2011), phytoplankton ecology (Peperzak and Brussaard, 2011); and microbenthology - i.e. benthic microalgae, ciliates, flagellates and foraminiferans (Bernhard et al., 2003, 2006; Pucci et al., 2009; First and Hollibaugh, 2010; Figueira et al., 2012, Langlet et al., 2013a,b). The use of CTG for metazoan organisms, however, has so far been limited to dysoxic laminated sediments in 400 to $600 \mathrm{~m}$ water depth (oxygen minimum zone in the Santa Barbara
Basin; Bernhard et al., 2003), and deep-sea (3300 to $3600 \mathrm{~m}$ ) anoxic sediments (Mediterranean; Danovaro et al., 2010). Here, we specifically test its usefulness to quantify live meiofauna (harpacticoid copepods, nematodes) in coastal sublittoral anoxic vs. oxic sediments.

As in most marine sediments, harpacticoid copepods (Crustacea, Copepoda) and nematodes (Nematoda) are the two most abundant meiofauna taxa in the soft sublittoral sediment in the Gulf of Trieste, northern Adriatic Sea (Vrišer, 1984; Travisi, 2000; Grego et al., 2009). The two groups are morphologically very different and are known to have very different tolerances to low dissolved oxygen conditions. Copepods are in general more sensitive; according to Vernberg and Coull (1975) they tolerate anoxia from $1 \mathrm{~h}$ (sand dwellers) to a maximum of 5 days (mud dwellers). They show a drop in abundance and diversity with progressing hypoxia/anoxia (Hicks and Coull, 1983; Moore and Bett, 1989; Murrell and Fleeger, 1989; Moodley et al., 1997; Modig and Ólafsson, 1998; Wetzel et al., 2001; Levin, 2003). Grego et al. (2013) describes the change in copepod community composition due to anoxia in more detail. Nematodes, in contrast, can survive up to several months of extended periods of hypoxia/anoxia and show little decrease in biodiversity before the system reaches longer term anoxic conditions (Josefson and Widbom, 1988; Murrell and Fleeger, 1989; Austen and Wibdom, 1991; Hendelberg and Jensen, 1993; Wetzel et al., 2001; Levin, 2003; Van Colen et al., 2009). In oxygen minimum zones, for example, nematodes are found in higher densities (Veit-Köhler et al., 2009) compared to surrounding well-oxygenated sediments, presumably benefitting from high food supply and low predation and competition pressure (Neira et al., 2001). Certain species, however, are exceptions: copepods that tolerate anoxia (Vopel et al., 1998) or surface-dwelling species of nematodes that die when oxic conditions become hypoxic (Modig and Ólafsson, 1998). It is difficult to define the impact of oxygen concentration alone on benthic communities because, with the progress of hypoxia to anoxia, the concentration of sulfide increases. Sulfide is toxic for most of the fauna, although some species have developed strategies to detoxify it (Vaquer-Sunyer and Duarte, 2010). Some nematode species inhabit thiobiotic environments (Wetzel et al., 2001; Ott et al., 2004, 2005), but no such evidence has been reported for copepods.

Due to the often rapid onset of anoxia and its sometimes short duration, well-designed experiments are needed to distinguish between still living and recently dead meiofauna at the time of sampling. This is even more important for differentiation between sensitive and tolerant species within the respective taxa. Based on initial successes with the CTG labelling method in foraminiferan studies (Bernhard et al., 2006; Pucci et al., 2009), we applied this method to another set of meiofauna organisms, namely copepods and nematodes. Here we test whether the CTG labelling is a more accurate method than the widely used RB staining for quantifying living meiofauna in hypoxia/anoxia studies. The primary 


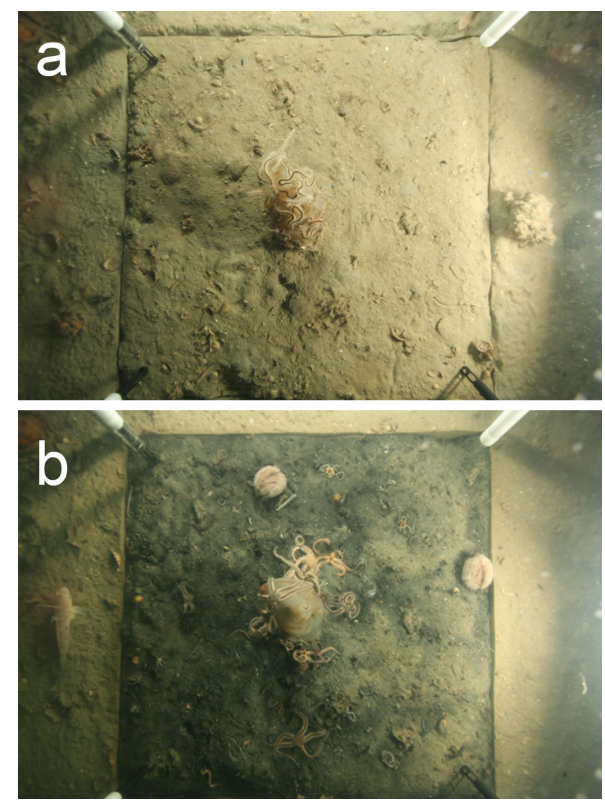

Fig. 1. Image of sediment surface enclosed by the benthic chamber at the beginning of the deployment (a) and after 5 days of oxygen decline (b), before taking core samples. Note dark colour of sediment compared to outside; sensors visible in corners. Centre: the ascidian Phallusia mammilata, dead and partly overturned brittle stars Ophiothrix quinquemaculata along with various infaunal worms. Top and right: two emerged infaunal sea urchins Schizaster canaliferus.

goal of the work described here was to compare harpacticoid copepod and nematode density in normoxic sediment samples with those in anoxic samples. Anoxia was experimentally induced by means of an underwater chamber (Stachowitsch et al., 2007, Riedel et al., 2013). A significant difference in meiofauna density between the two staining techniques could point to a major influence of the staining used, and thus on the final interpretation of ecological studies on meiofauna. Therefore this methodological test on both major meiofauna taxa (copepods, nematodes) will yield well-grounded advice for future staining procedures in meiofauna research.

\section{Material and methods}

\subsection{Experimental set-up}

The experiment was performed in the northern Adriatic Sea (Mediterranean) under the oceanographic buoy of the Marine Biology Station Piran $\left(45^{\circ} 32.90^{\prime} \mathrm{N}, 13^{\circ} 33.00^{\prime} \mathrm{E}\right)$ in $24 \mathrm{~m}$ depth on a poorly sorted silty sand bottom. Artificial hypoxia and anoxia was created with a underwater chamber $(50 \times 50 \times 50 \mathrm{~cm})$, originally designed to document the macrofauna epi- and infauna behaviour during oxygen decline. The separate lid houses a time-lapse camera (images taken in 6 min intervals), 2 flashes, battery packs, a microsen-

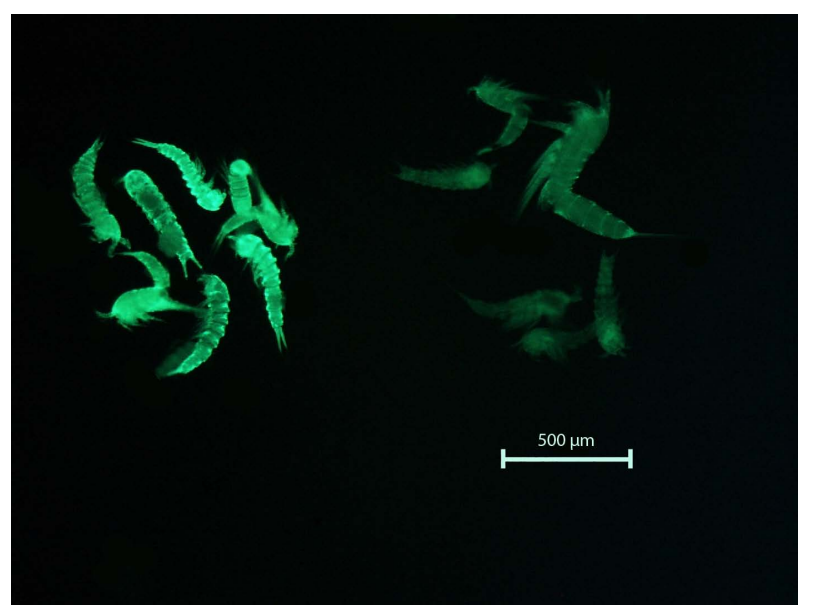

Fig. 2. Representative sample of CTG-labelled harpacticoid copepods. Left: strongly fluorescing (living) specimens, right: weakly stained (dead) individuals.

sor array (dissolved oxygen, hydrogen sulfide, temperature) plus datalogger (Unisense ${ }^{\circledR}$ ). The sensors were positioned $2 \mathrm{~cm}$ above the sediment; measurements were taken in $1 \mathrm{~min}$ intervals. $\mathrm{pH}$ was recorded at the beginning and end of the deployment with a WTW TA $197 \mathrm{pH}$ sensor. For more details on the method see Stachowitsch et al. (2007). For this experiment, the plexiglass chamber plus lid was positioned at the bottom without abundant macroepifauna or without major traces and structures such as mounds or pits that would indicate the presence of larger infauna species. One ascidian and 2-3 brittle stars were placed on the sediment inside the chamber to better visually follow and verify the oxygen decline based on their behaviour (Riedel et al., 2008). To promote the oxygen decline (consumption), 2 additional ascidians were put into mesh bags hanging from the lid.

The chamber was deployed for 5 days from 8-12 August 2009. Dissolved oxygen concentration (initial value ca. $5.5 \mathrm{mLL}^{-1}$ ) steadily dropped and reached beginning hypoxia $\left(2 \mathrm{mLL}^{-1}\right)$ in $12 \mathrm{~h}$, and anoxia in $48 \mathrm{~h}$ after chamber closure. At the transition from severe hypoxia $\left(0.5 \mathrm{mLL}^{-1}\right)$ to anoxia, almost all epifaunal brittle stars were dead and the sediment started to turn greyish black due to the development of hydrogen sulfide $\left(\mathrm{H}_{2} \mathrm{~S}\right.$; final value ca. $\left.30 \mu \mathrm{mol} \mathrm{L}{ }^{-1}\right)$ reacting with reduced Fe to form FeS. During ongoing anoxia, one sipunculid and two infaunal sea urchins, Ova canaliferus (Fig. 1), emerged from the sediment. The temperature within the chamber remained constant $\left(20.1^{\circ} \mathrm{C}\right)$; the bottom water salinity was $38 \mathrm{PSU}$. The average $\mathrm{pH}$ dropped from 8.1 to 7.6 by the end of the experiment.

Meiofauna cores (inner diameter $4.6 \mathrm{~cm}$ ) were taken by scuba divers. Eight cores were randomly taken outside the chamber (normoxia control treatments) and another eight cores were taken inside the chamber before the experiment was terminated (anoxia) (see Fig. 1). All cores were immediately transported to the laboratory in cooling boxes and 
transferred into a thermostatic room with in situ temperature. The cores were sliced at $0.5 \mathrm{~cm}$ intervals until $2 \mathrm{~cm}$ depth (and below this in $1 \mathrm{~cm}$ steps down to $5 \mathrm{~cm}$ depth). The sliced sediment was placed into separate $250 \mathrm{~mL}$ containers. For this study, 6 anoxia cores ( 3 stained with RB and 3 with CTG) and 6 normoxia cores ( 3 stained with RB and 3 with CTG) were analysed down to $2 \mathrm{~cm}$ depth. The two remaining cores were taken as backup cores.

\subsection{Labelling/staining protocol}

CellTracker Green 5-chloromethylfluorescein diacetate (CellTracker $^{\mathrm{TM}}$ Green CMFDA; Molecular Probes, Invitrogen Detection Technologies) is a fluorescent probe. When living cells are incubated in CTG, the probe passes through the cellular membrane and reaches the cytoplasm, where hydrolysis with nonspecific esterase produces the fluorogenic compound which is observed with the accurate excitation $(492 \mathrm{~nm})$ and emission wavelength $(517 \mathrm{~nm})$. Unlike other fluorogenic substances, Cell-Tracker Green CMFDA does not leak out of the cell via ion channels in the cell membrane once it is incorporated (Bernhard et al., 2006; Pucci et al., 2009).

Rose bengal (4,5,6,7-tetrachloro- $2^{\prime}, 4^{\prime}, 5^{\prime}, 7^{\prime}$ tetraiodofluorescein disodium salt) is a widely used bulk stain (Higgins and Thiel, 1988; Somerfield et al., 2005) that adheres to (cytoplasmatic) proteins, regardless of whether the cell/animal is dead or alive (Bernhard et al., 2006). It colours different meiofauna organisms differently (Giere, 2009) and has the advantage of being cheap and easy to apply, and only a light microscope is required; on the negative side it is a nonvital stain.

The overlying seawater from the cores $(10 \mathrm{~mL})$ was added into each $250 \mathrm{~mL}$ container including the sediment slices. For CTG labelling, $1 \mathrm{mg}$ of CTG (stored at $-20^{\circ} \mathrm{C}$ ) was dissolved in $1 \mathrm{~mL}$ dimethyl sulfoxide (DMSO). The final concentration of CTG/DMSO solution was $\approx 1 \mu \mathrm{M}$, corresponding roughly to $\approx 5 \mu \mathrm{L} \mathrm{CTG/DSMO} \mathrm{per} 10 \mathrm{~mL}$ of sediment and liquid together. Overall, $10 \mu \mathrm{L}$ of the CTG/DSMO solution was added to the sediment-overlying water with a micropipette. The containers were incubated at in situ temperature in the dark for $12 \mathrm{~h}$. Afterwards, samples were fixed in $4 \%$ borax-buffered $\left(5 \mathrm{gL}^{-1}\right)$ formalin. For RB staining, the $\mathrm{RB}$ was applied as $1 \mathrm{gL}^{-1}$ solution (in $10 \%$ formalin) into fixed samples ( $4 \%$ borax-buffered formalin) to yield a final $1 \%$ solution (Higgins and Thiel, 1988; Somerfield et al., 2005).

\subsection{Meiofauna extraction and counting}

The samples were processed following the common meiofauna protocol (De Jonge and Bouwman, 1977; McIntyre and Warwick, 1984). Formalin-fixed sediment samples were washed with tap water to eliminate formalin and clay by pouring them on a $38 \mu \mathrm{m}$ sieve. The sediment recovered
Table 1. Three-way ANOVA for factors method, oxygen and layer (depth of the sediment). The copepod abundances were logtransformed for the calculation. Significant factors or interactions are bolded $(p<0.05)$.

\begin{tabular}{lrrrrr}
\hline Copepods & Df & Sum Sq & Mean Sq & $F$ value & $\operatorname{Pr}(>F)$ \\
\hline Layer & 3 & 95.09 & 31.7 & 298.302 & $\mathbf{0 . 0 0 0 0 0 0}$ \\
Oxygen & 1 & 5.5 & 5.5 & 51.805 & $\mathbf{0 . 0 0 0 0 0 0}$ \\
Method & 1 & 4.9 & 4.9 & 46.089 & $\mathbf{0 . 0 0 0 0 0 0}$ \\
Layer: oxygen & 3 & 1.83 & 0.61 & 5.734 & $\mathbf{0 . 0 0 2 8 4 0}$ \\
Layer: method & 3 & 0.92 & 0.31 & 2.88 & 0.050660 \\
Oxygen : method & 1 & 2.52 & 2.52 & 23.732 & $\mathbf{0 . 0 0 0 0 2 7}$ \\
Layer: oxygen : method & 3 & 0.29 & 0.1 & 0.895 & 0.453810 \\
Residuals & 33 & 3.51 & 0.11 & & \\
\hline
\end{tabular}

on the $38 \mu \mathrm{m}$ sieve was transferred into $1 \mathrm{dL}$ centrifuge tubes and a Levasil ${ }^{\circledR}$ (distilled-water) solution (specific density $=1.17 \mathrm{~g} \mathrm{~cm}^{-3}$ ) was added and gently mixed through the sediment prior to centrifugation. After centrifugation, the soft-bodied meiofauna was retained in the floating phase. Copepods and nematodes were counted using a Nikon SMZ 800 binocular microscopes equipped with a Nikon INTENSILIGHT C-HGFI for UV production and an A 488 filter. CTG samples containing a large number of animals (surface layers of normoxic sediment) were split into several petri dishes to avoid long exposure of animals to UV light in order not to lose fluorescence.

\subsection{Data treatment}

Analyses were performed using the $\mathrm{R}$ statistical software package (Team, 2010). The nematode and copepod data were first tested for normality with Lilliefors (KolmogorovSmirnov) test using the "nortest" package. The nematode abundance data followed the normal distribution, whereas copepod abundance data were significantly different from normal and showed a positively skewed distribution; therefore the data were log-transformed for the calculations of three-way factorial ANOVA (Dytham, 2003; Sokal and Rohlf, 1995). The three-way factorial ANOVA was calculated for copepods and for nematodes separately to test for significant differences $(p<0.05)$ among three factors: method (CTG vs. RB), oxygen (anoxia vs. normoxia) and sediment layer $(0-0.5 \mathrm{~cm}, 0.5-1 \mathrm{~cm}, 1-1.5 \mathrm{~cm}, 1.5-2 \mathrm{~cm}$ vertical sediment depth). The relationships of first-order interactions (oxygen $X$ method, oxygen $X$ depth and depth $X$ method) were plotted on the graphs, where the third factor (not shown) was averaged (Sokal and Rohlf, 1995).

\section{Results and discussion}

The experimental design (Stachowitsch et al., 2007) successfully mimicked the hypoxic and anoxic conditions and associated meiofaunal responses in the expected time frames. For the first time, the CTG technique was applied specifically to label two main groups of meiofauna, copepods 


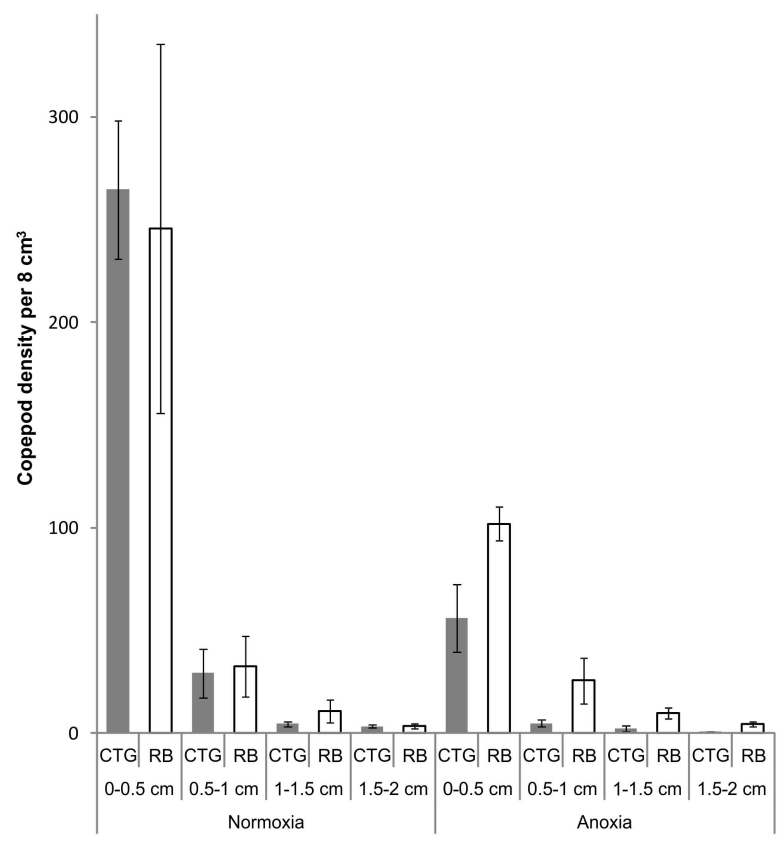

Fig. 3. CTG-labelled vs. RB-stained copepod density in normoxia and after experimental anoxia in four sediment depth layers. Average values $( \pm \mathrm{STD})$ are calculated from three replicates.

and nematodes, in an attempt to document the course of an oxygen deficiency event more precisely. Especially in modern, short-term, process-oriented studies, definitive determinations of living and dead components are essential. This approach is much more satisfactory and fine scaled than comparing samples from different times and distinguishing communities based on presence/absence.

\subsection{Meiofauna densities}

The copepods, as the most sensitive meiofauna group to oxygen depletion (Hicks and Coull, 1983; Moore and Bett, 1989; Moodley et al., 1997), were of primary interest here. We found a significant drop in copepod density from normoxia to anoxia (factor oxygen, Table 1) regardless of the staining/labelling technique (Fig. 3). Moreover, the density was significantly higher in the surface layers with both techniques (factor layer, Table 1). Copepod density is also significantly affected by the method used (factor method, Table 1). Under normoxic conditions there was no difference in the number of living copepods between both methods, in any sediment layer (Fig. 3). However, comparing the CTG and RB method in the anoxic conditions, RB staining revealed a higher number of living copepods in all depth layers. The density of RB stained copepods was nearly 2 times higher in the top layer (56 \pm 16.5 vs. $102 \pm 8.2$ for CTG and RB, respectively) and 5 times in the lower layers $(0.5-1 \mathrm{~cm}, 1-1.5 \mathrm{~cm}, 1.5-2 \mathrm{~cm})$ of anoxia (Fig. 3). This explains the significant interaction of the factors oxygen and method as the method was rele-
Table 2. Three-way ANOVA for factors method, oxygen and layer (depth of the sediment). The calculation was done on nematode abundances. Significant factors or interactions are bolded $(p<$ $0.05)$.

\begin{tabular}{lrrrrr}
\hline Nematodes & Df & Sum Sq & Mean Sq & $F$ value & $\operatorname{Pr}(>F)$ \\
\hline Layer & 3 & 90310 & 30103 & 5.383 & $\mathbf{0 . 0 0 3 9 6 0}$ \\
Oxygen & 1 & 29277 & 29277 & 5.235 & $\mathbf{0 . 0 2 8 6 7 0}$ \\
Method & 1 & 216395 & 216395 & 38.697 & $\mathbf{0 . 0 0 0 0 0 1}$ \\
Layer: oxygen & 3 & 81667 & 27222 & 4.868 & $\mathbf{0 . 0 0 6 5 2 0}$ \\
Layer: method & 3 & 2083 & 694 & 0.124 & 0.945170 \\
Oxygen: method & 1 & 4510 & 4510 & 0.806 & 0.375670 \\
Layer: oxygen: method & 3 & 5334 & 1778 & 0.318 & 0.812280 \\
Residuals & 33 & 184535 & 5592 & & \\
\hline
\end{tabular}

vant only in anoxic circumstances (Table 1). In normoxia the copepod abundance was very similar for CTG and RB (Fig. 6a). In anoxia, however, there is the trend of higher copepod abundance in RB versus CTG (Fig. 6a). The three-way ANOVA (Table 1) indicates a significant interaction also for the factors oxygen and layer (demonstrated on Fig. 6b) because there is a huge difference in the copepod abundance between anoxia and normoxia especially in the top sediment layer, but not in deeper layers. The interaction of layer and method was not significant, as the same trend of decreasing copepod abundance with sediment depth was observed for both methods (see parallel lines in Fig. 6c).

Although we found significant differences in the density of copepods between normoxia and anoxia already with RB staining (De Troch et al., 2013), the density is greatly overestimated with the RB method. Importantly, the CTG labelled only the animals that were still alive at the time of fixation. Accordingly, with CTG we can extract from the samples only the true surviving species of short-term anoxia (more information in Grego et al., 2013). This provides highly relevant information in connection with impact studies.

The nematode density, as the copepod density, was also significantly affected by each factor separately (method, oxygen and sediment layer, Table 2, Fig. 5). When analysing the impact of oxygen (normoxia/anoxia) solely on the RBstained nematodes, De Troch et al. (2013) did not find a significant effect, mainly due to high variation of nematode abundance, when stained with RB. When the CTG-labelled nematode densities are integrated in three-way ANOVA calculations (in the deeper layers of anoxia the CTG densities are much lower than RB) the factor oxygen becomes significant. The interaction of factors oxygen and method was not significant (Table 2, Fig. 7a), as regardless of staining method, the density of nematodes slightly dropped from normoxia to anoxia. The interaction of factors oxygen and depth is significant as in normoxia the peak of nematode density is in the second layer $(0.5-1 \mathrm{~cm})$, while in anoxia the density decreases linearly with depth (Table 2, Fig. 7b). The application of different staining methods to various sediment layers (layer and method) did not affect the trend of nematode 


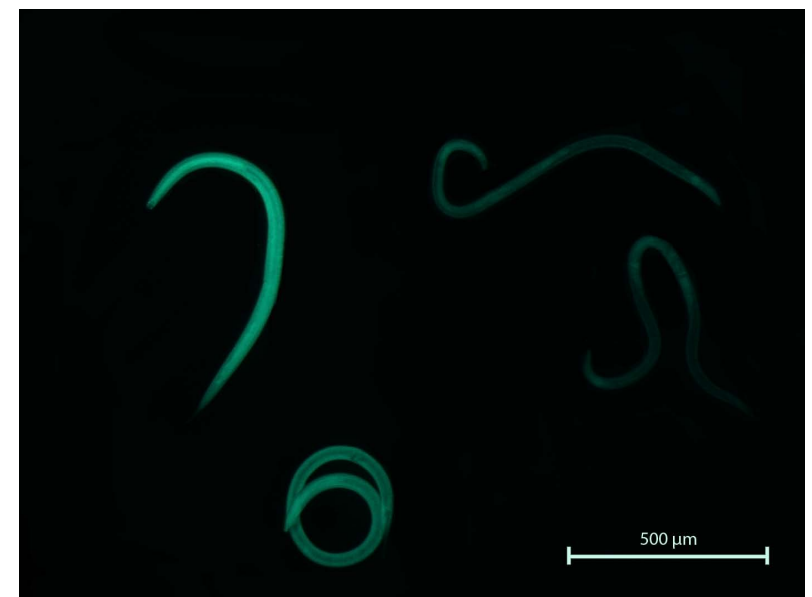

Fig. 4. Four CTG-labelled nematodes. CTG distinguishes living individuals (left two) from those that appear to be morphologically intact but are actually dead (two right).

density, which is generally decreasing with depth (parallel lines-Table 2, Fig. 7c).

In contrast to what we found for copepods and what Bernhard et al. (2006) found for foraminiferans, where the RB significantly overestimated the abundances in anoxia, for nematodes it was not so, at least not in all sediment layers (Fig. 5). There were no differences in nematode abundance if labelled with CTG or stained with RB in top anoxic layer. The RB overestimated the abundances in the top sediment layer of normoxia (139.3 \pm 24.0 vs. $300.8 \pm 101.1$ for CTG and RB, respectively) (Fig. 5). Also in the $1-1.5 \mathrm{~cm}$ layer of normoxia the abundances were significantly higher with RB. The presence of lower numbers of live - CTG-labelled - nematodes in top normoxic layer might reflect the short generation time of some species, namely days to weeks (Platt et al., 1985; Martinez et al., 2012). Even though the decomposition is relatively fast (Kammenga et al., 1996), nematodes do not disintegrate within hours/days; therefore the density of living nematodes may be overestimated in ecological/monitoring studies based solely on RB staining. As RB stains all material containing proteins, the presence of different material on, for example, the cuticula of nematodes can contribute to an overestimate of living organisms. This finding has important implications for future counts based on RB-stained samples. Also the variation of the nematode abundance between replicates is much higher for nematodes stained with $\mathrm{RB}$, especially in deeper sediment layers of anoxic treatment (Fig. 5). This implies that the CTG method is more accurate. This high variation with the RB method could be due to the presence of many already dead but not yet decomposed nematodes in RB anoxic samples. In contrast, the abundance of survivors is similar in all CTG-labelled cores.

Oxygen is the most important abiotic variable to determine the vertical distribution of meiofaunal organisms (Gray and Elliot, 2009); the same holds true in oxygen minimum

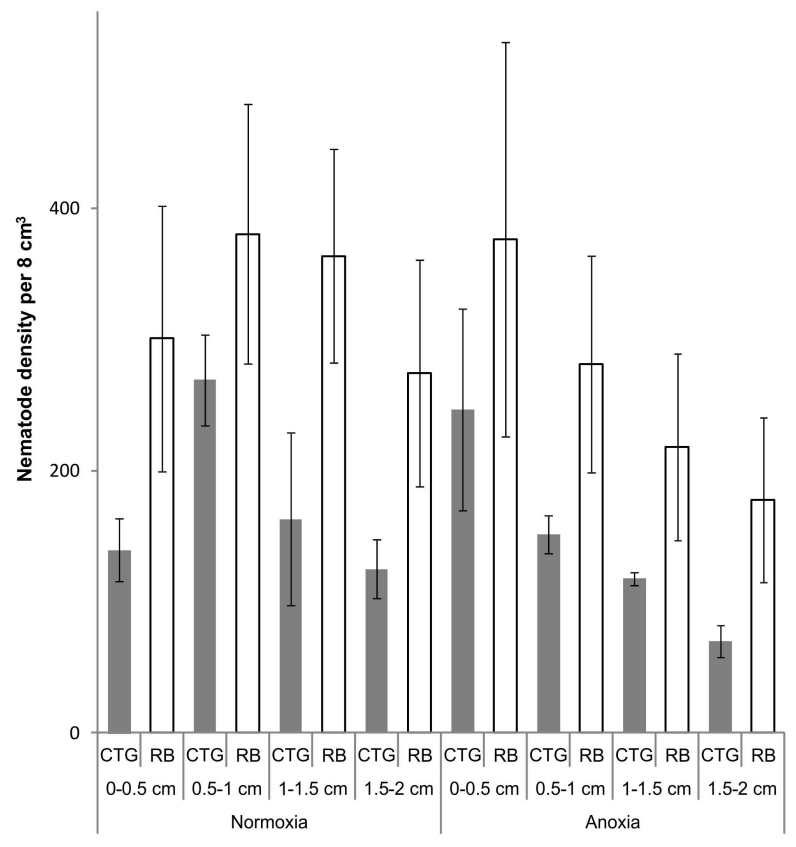

Fig. 5. CTG-labelled vs. RB-stained nematode density in normoxia and after experimental anoxia in four sediment depth layers. Average values $( \pm$ STD) are calculated from three replicates.

zones, where the copepod density was positively correlated with oxygen concentration (Levin et al., 2002). Nematodes, in contrast, were shown to be most tolerant to anoxic stress (Josefson and Widbom, 1988; Murrell and Fleeger, 1989; Hendelberg and Jensen, 1993; Moodley et al., 1997; Modig and Ólafsson, 1998; Levin, 2003). The mortality and depth distribution of nematodes depend mainly on the length of anoxia, and can drop markedly, even by a third already after a 14-day exposure to anoxia (Steyaert et al., 2007). Some nematode species, however, are known to inhabit anoxic layers (Soetaert and Heip, 1995; Steyaert et al., 2007) and show a negative correlation with oxygen concentrations (Levin et al., 2002). In our shorter-term experiment the overall nematode density did not show a major decrease at anoxia. Rather, we detected an accumulation of individuals in the top layer and lower densities in the deeper layers with both staining techniques (Figs. 5, 7b). We attribute this to an upward migration of nematodes towards the sediment surface under anoxic conditions, as reported elsewhere (Hendelberg and Jensen, 1993).

Sutherland et al. (2007) pointed to an important effect of free sulfide that is formed in anoxic conditions. They found weak correlations between free sulfide concentration and the number of nematodes, while clear trends occurred between free sulfide and numbers of crustaceans. The crustaceans were represented mainly by copepods, and with increasing concentration of free sulfide the number of copepods dropped. This is in accordance with our study. The free sulfide concentrations rose up to $30 \mu \mathrm{mol} \mathrm{L}^{-1}$ in 
anoxia (in the water column), which is above the level causing significant negative effects on marine benthic organisms (>14 $\mu \mathrm{mol} \mathrm{L}^{-1}$; Vaquer-Sunyer and Duarte, 2010). The small influence of sulfide on nematodes can be explained by adaptive strategies. The nematode community inhabiting the deeper sediment layers $(0.5-2 \mathrm{~cm})$ is therefore already adapted to sulfide (Mirto et al., 2000), while copepods are not adapted, as they are mainly abundant in the top layer $(0-$ $0.5 \mathrm{~cm}$ ), which is better oxygenated. The muddy sediment of the northern Adriatic Sea often lacks oxygen and contains high concentrations of free sulfide during warm periods with strong water stratification (Faganeli et al., 1991; Hines et al., 1997).

Finally, the mortality of nematodes during sample handling may play a role. Such mortality is indicated by a significant difference between RB and CTG techniques in nematode numbers in normoxic samples, but no such difference was found for copepod numbers in normoxic samples. Nematodes may be more sensitive to physical disturbance during sediment slicing and sediment mixing while applying the CTG label. Also, some species from the northern Adriatic muddy community can be sensitive to high oxygen concentrations during sample processing. Wetzel et al. (2001) and references therein state that nematodes from poorly oxygenated muddy sites can be intolerant to well-oxygenated interstitial waters.

\subsection{Labelling/staining implications}

As in all staining techniques, staining is seldom an all-ornothing phenomenon. The copepods and nematodes stained with RB showed different intensity in colouration, but only the empty exuvia of copepods or unstained nematodes could be definitely determined as dead. When labelled with CTG, some organisms shined brightly green, and were classified as living at the time of sampling (Fig. 2 left, Fig. 4 left). Another set of individuals coloured only minimally - pale green - and were classified as dead at the time of sampling (Fig. 2 right, Fig. 4 right). The difference between the live and dead animals is similar to that outlined for foraminiferans by Pucci et al. (2009) and for loriciferans by Danovaro et al. (2010). Loriciferans that were frozen prior to the CTG labelling (and therefore dead; the enzymatic activity was inhibited and CTG could not label them) coloured pale green (Danovaro et al., 2010). It was helpful to pull all individuals together to simplify the distinction between these two levels of colouration. The intensity of the staining (RB) or fluorescence (CTG) varied also with different species of copepod or nematode. Elliott and Tang (2009) faced similar problems while staining with neutral red, also a vital stain. Moreover, bigger species absorbed more stain, as already reported by Elliott and Tang (2009).

RB staining is a classical procedure in benthic ecology (Elefteriou and McIntyre, 2005; Giere, 2009) and stains proteins that can be preserved well in dead animals for lengthier a

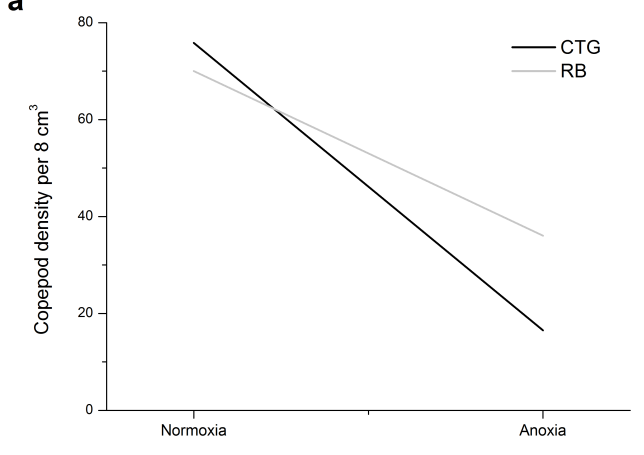

b

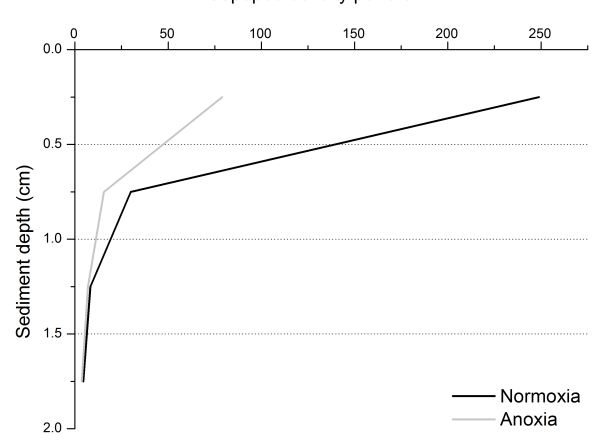

c

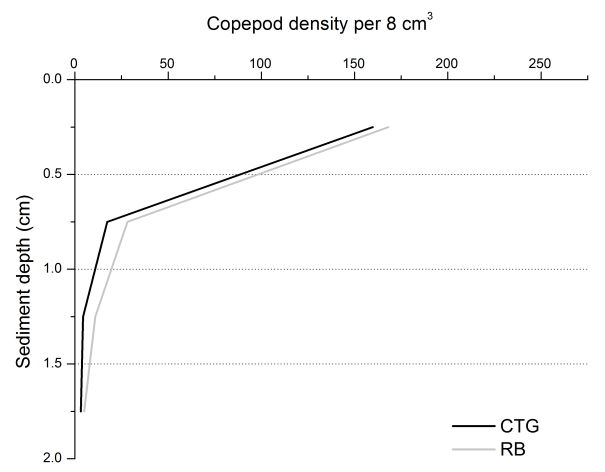

Fig. 6. First-order interactions of three-way ANOVA for factors (a) oxygen $X$ method, (b) oxygen $X$ depth and (c) depth $X$ method. The geomean of copepod abundance is given. For each graph, the third factor (that is not shown) was averaged.

periods (Murray and Bowser, 2000). The CTG method, in contrast, enables the detection of actively metabolizing cells as it identifies the presence of respiratory activity (Bernhard et al., 2006; Pucci et al., 2009). The CTG technique, however, can have certain peculiarities. The first involves the duration of post-mortem enzymatic activity (Borrelli et al., 2011). The residual esterase activity in microbes produced around $25 \%$ of fluorescence after heat killing, still $48 \mathrm{~h}$ after treatment (Kaneshiro et al., 1993). At the same time, foraminifera killed $1 \mathrm{~h}$ prior to staining did not exhibit any fluorescence (Bernhard et al., 1995), indicating only shortlived post-mortem esterase activity. The latter is currently 
unknown in copepods, but Bergvik et al. (2012) recently showed that planktonic calanoid copepods exhibited activity of autolytic enzymes soon after death, speeding up their decomposition. We therefore assume that vital functions, necessary to activate the fluorescent probe CTG, are diminished soon after death. The second feature of the CTG technique is that it also labels bacterial stocks (Pucci et al., 2009). In our samples, for example, the empty exuvia (carapace) of the copepods were not labelled, but the area of joints was shiny due to bacterial aggregation here (i.e. the largest copepod individual on the top right side in Fig. 2); this did not affect the distinction between dead and living individuals. The third CTG feature to consider is that the working time must be rationalized because CTG fluorescence slowly fades with working time under UV light. Finally, although Danovaro et al. (2010) incubated the Loriciferans with CTG probe at sea level pressure, Elliott and Tang (2009) suggest that such live stains/labels should not be applied for deep-sea animals or other animals inhabiting specific environments whose variables cannot be reproduced in the laboratory, causing the animals to die during incubation.

The examination of living fauna (Steyaert et al., 2007) prior to fixation is clearly one alternative to CTG. However, the determination of live copepods or nematodes can be misleading here as well: individuals can be immobile but actually still alive. Moreover, the time needed to examine the living fauna in multiple replicated and big samples is typically too long to treat all samples equally.

\section{Conclusions}

In conclusion, our results show that the CTG technique well distinguished living from dead organisms and is a suitable staining method to document the response of selected meiofauna groups to short-term disturbances. The common trend is that RB markedly overestimates the number of survivors in both taxa. Specifically, the CTG technique was able to pinpoint a turning point in copepod density from normoxia to anoxia, whereas traditional RB staining failed to resolve this event properly. When the copepods and nematodes are dead, but not yet decomposed, the RB will stain them equally as live ones, especially if they are freshly dead. Therefore, copepods and nematodes that died in the course of the experiment can only be enumerated, and excluded, with CTG labelling.

Importantly, CTG helps to better determine more tolerant species that survived the respective level of disturbance. We therefore conclude that for normal monitoring of meiofauna diversity under undisturbed conditions, RB is an efficient method. If the task is to examine survival of animals in hypoxia, anoxia or other types of disturbance, and a binocular microscope equipped with proper UV production light and filter is available, then we highly recommend the CTG technique. This echoes the recommendation of foraminiferan researchers.
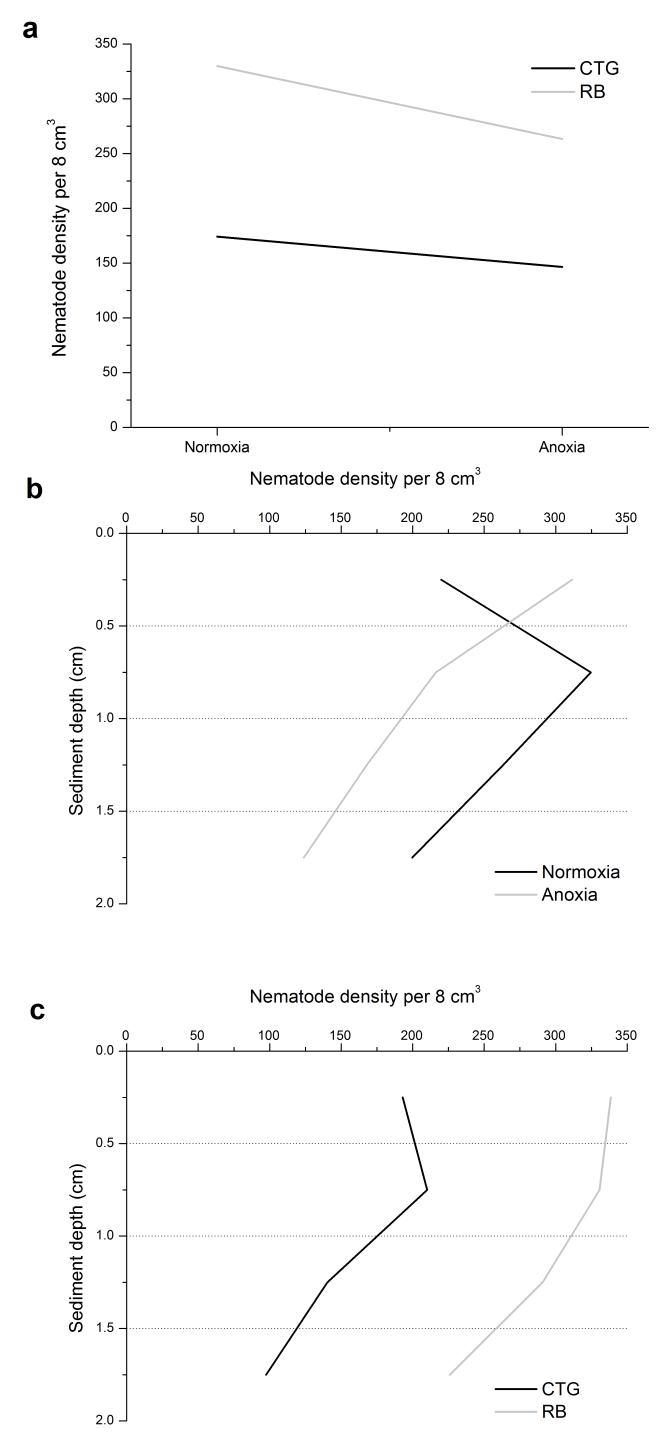

Fig. 7. First-order interactions of three-way ANOVA for factors (a) oxygen $X$ method, (b) oxygen $X$ depth and (c) depth $X$ method. The mean of nematode abundance is given. For each graph, the third factor (that is not shown) was averaged.

Acknowledgements. The present study was financed by the Austrian Science Fund (FWF; project P21542-B17) and supported by the OEAD Bilateral Slovenian Austrian Scientific Technical Cooperation project SI 22/2009. We thank Emmanuelle Geslin for her suggestion to use CTG for meiofauna labelling; Christian Baal and Frans Jorissen for introduction to the CTG method; the Department of Molecular Evolution (University of Vienna; head Ulrich Technau) for allowing us to use their epifluorescence binocular; Grigory Genikhovich and Johanna Krauswas for help with the photography; Jörg Ott for help in determining nematode viability; Boris Petelin for LaTex instructions; and Milijan Šiško, Tihomir Makovec and Janez Forte for support. The third author is a postdoctoral fellow financed by the Special Research Fund of Ghent University (GOA project 01GA1911W).

Edited by: J. Bernhard 


\section{References}

Austen, M. C. and Wibdom, B.: Changes in and slow recovery of a meiobenthic nematode assemblage following a hypoxic period in the Gullmar Fjord basin, Sweden, Mar. Biol., 111, 139-145, doi:10.1007/bf01986355, 1991.

Bergvik, M., Overrein, I., Bantle, M., Evjemo, J. O., and Rustad, T.: Properties of Calanus finmarchicus biomass during frozen storage after heat inactivation of autolytic enzymes, Food Chem., 132, 209-215, 2012.

Bernhard, J. M.: Distinguishing live from dead foraminifera: methods rewiew and proper applications, Micropaleontology, 46, 3846, 2000.

Bernhard, J. M., Newkirk, S. G., and Bowser, S. S.: Towards a nonterminal viability assay foraminiferan protists, J. Eukaryot. Microbiol., 42, 357-367, 1995.

Bernhard, J. M., Visscher, P. T., Bowser, S. S.: Submillimeter life positions of bacteria, protists, and metazoans in laminated sediments of the Santa Barbara Basin, Limnology and Oceanography, 48, 813-828, doi:10.4319/lo.2003.48.2.0813, 2003.

Bernhard, J. M., Ostermann, D. R., Williams, D. S., and Blanks, J. K.: Comparison of two methods to identify live benthic foraminifera: a test between Rose Bengal and CellTracker Green with implications for stable isotope paleoreconstructions, Paleoceanography, 21, 1-8, doi:10.1029/2006pa001290, 2006.

Boleti, H., Ojcius, D. M., and Dautry-Varsat, A.: Fluorescent labelling of intracellular bacteria in living host cells, J. Microbiol. Methods, 40, 265-274, 2000.

Borrelli, C., Sabbatini, A., Luna, G. M., Nardelli, M. P., Sbaffi, T., Morigi, C., Danovaro, R., and Negri, A.: Technical Note: Determination of the metabolically active fraction of benthic foraminifera by means of Fluorescent In Situ Hybridization (FISH), Biogeosciences, 8, 2075-2088, doi:10.5194/bg-8-20752011, 2011.

Danovaro, R., Dell'Anno, A., Pusceddu, A., Gambi, C., Heiner, I., and Kristensen, R. M.: The first metazoa living in permanently anoxic conditions, BMC Biol., 8, 30, doi:10.1186/1741-7007-830, 2010.

De Jonge, V.-N. and Bouwman, L. A.: A simple density separation technique for quantitative isolation of meiobenthos using the colloidal silica Ludox-TM, Marine Biol., 42, 143-148, 1977.

De Troch, M., Roelofs, M., Riedel, B., and Grego, M.: Structural and functional responses of harpacticoid copepods to anoxia in the Northern Adriatic: an experimental approach, Biogeosciences, in preparation, 2013.

Diaz, R. J. and Rosenberg, R.: Spreading dead zones and consequences for marine ecosystems, Science, 321, 926-929, 2008.

Dytham, C.: Choosing and Using Statistics: A Biologist's Guide, 2nd edn., Blackwell Science, Oxford, 2003.

Elefteriou, A. and McIntyre, A.: Methods for the Study of Marine Benthos, 3rd Edn., Oxford, Blackwell Science Ltd., 418 pp., 2005.

Elliott, D. T. and Tang, K. W.: Simple staining method for differentiating live and dead marine zooplankton in field samples, Limnol. Oceanogr. Methods, 7, 585-594, 2009.

Faganeli, J., Avčin, A., Fanuko, N., Malej, A., Turk, V., Tušnik, P., Vrišer, B., and Vukovič, A.: Bottom layer anoxia in the central part of the Gulf of Trieste in the late summer of 1983, Mar. Pollut. Bull., 16, 75-78, doi:10.1016/0025-326x(85)90127-4, 1985.
Faganeli, J., Pezdič, J., Ogorelec, B., Herndl, G. J., and Dolenc, T.: The role of sedimentary biogeochemistry in the formation of hypoxia in shallow coastal waters (Gulf of Trieste, northern Adriatic), in: Modern and Ancient Continental Shelf Anoxia, edited by: Tyson, R. V. and Pearson, T. H., The Geological Society, London, 107-117, 1991.

Figueira, B., Grebfell, H. R., Hayward, B. W., and Alfaro, A. C.: Comparison of Rose Bengal and CellTracker Green staining for identification of live salt-marsh foraminifera, J. Foramin. Res., 42, 206-215, 2012.

First, M. R. and Hollibaugh, J. T.: Diel depth distributions of microbenthos in tidal creek sediments: high resolution mapping in fluorescently labeled embedded cores, Hydrobiologia, 655, 149158, doi:10.1007/s10750-010-0417-2, 2010.

Giere, O.: Meiobenthology: the Microscopic Motile Fauna of Aquatic Sediments, 2009.

Gooday, A. J., Jorissen, F., Levin, L. A., Middelburg, J. J., Naqvi, S. W. A., Rabalais, N. N., Scranton, M., and Zhang, J.: Historical records of coastal eutrophication-induced hypoxia, Biogeosciences, 6, 1707-1745, doi:10.5194/bg-6-1707-2009, 2009.

Gray, J. S. and Elliot, M.: Ecology Of Marine Sediments: From Science To Management, Oxford University Press, Oxford, 2009.

Grego, M., De Troch, M., Forte, J., and Malej, A.: Main meiofauna taxa as an indicator for assessing the spatial and seasonal impact of fish farming, Mar. Pollut. Bull., 58, 1178-1186, 2009.

Grego, M., Stachowitsch, M., De Troch, M., and Riedel, B.: Meiofauna winners and losers of coastal hypoxia: case study harpacticoid copepods, Biogeosciences, in preperation, 2013.

Heinz, P. and Geslin, E.: Ecological and biological responses of benthic foraminifera under oxygen-depleted conditions: laboratory approaches, in: Anoxia Evidence for Eukaryote Survival and Paleontological Strategies, edited by: Altenbach, A. V., Bernhard, J. M., and Seckbach, J., vol. 21, Springer, the Netherlands, 287-303, 2012.

Hendelberg, M. and Jensen, P.: Vertical distribution of the nematode fauna in a coastal sediment influenced by seasonal hypoxia in the bottom water, Ophelia, 37, 83-94, 1993.

Hicks, G. R. F. and Coull, B. C.: The ecology of marine meiobenthic harpacticoid copepods, Oceanogr. Mar. Biol. Ann. Rev., 21, 67175, 1983.

Higgins, R. P. and Thiel, H.: Introduction to the Study of Meiofauna, Smithsonian Institution Press, Washington, DC, 1988.

Hines, M. E., Faganeli, J., and Planinc, R.: Sedimentary anaerobic microbial biogeochemistry in the Gulf of Trieste, northern Adriatic Sea: influences of bottom water oxygen depletion, Biogeochemistry, 39, 65-86, 1997.

Josefson, A. B. and Widbom, B.: Differential response of benthic macrofauna and meiofauna to hypoxia in the Gullmar-Fjord Basin, Mar. Biol., 100, 31-40, 1988.

Justić, D., Rabalais, N. N., Turner, R. E., and Wiseman, W. J.: Seasonal coupling between riverborne nutrients, net productivity and hypoxia, Mar. Pollut. Bull., 26, 184-189, 1993.

Kammenga, J. E., VanKoert, P. H. G., Riksen, J. A. G., Korthals, G. W., and Bakker, J.: A toxicity test in artificial soil based on the life-history strategy of the nematode Plectus acuminatus, Environ. Toxicol. Chem., 15, 722-727, doi:10.1002/etc.5620150517, 1996. 
Kaneshiro, E. S., Wyder, M. A., Wu, Y.-P., and Cushion, M. T.: Reliability of calcein acetoxy methyl ester and ethidium homodimer or propidium iodide for viability assessment of microbes, J. Microbiol. Methods, 17, 1-16, 1993.

Langlet, D., Baal, C., Geslin, E., Metzger, E., Zuschin, M., Riedel, B., Stachowitsch, M., and Jorissen, F.: Foraminiferal specific responses to experimentally induced anoxia in the Adriatic Sea, Biogeosciences, in preparation, 2013a.

Langlet, D., Geslin, E., Baal, C., Metzger, E., Zuschin, M., Riedel, B., Stachowitsch, M., and Jorissen, F.: Foraminiferal survival after one year of experimentally induced anoxia, Biogeosciences, in preparation, $2013 \mathrm{~b}$.

Levin, L., Gutiérrez, D., Rathburn, A., Neira, C., Sellanes, J., Muñoz, P., Gallardo, V., and Salamanca, M.: Benthic processes on the Peru margin: a transect across the oxygen minimum zone during the 1997-98 El Niño, Progress Oceanogr., 53, 1-27, 2002.

Levin, L. A.: Oxygen minimum zone Benthos: adaptation and community response to hypoxia, Oceanogr. Mar. Biol. Ann. Rev., 41, $1-45,2003$.

Martinez, J. G., dos Santos, G., Derycke, S., and Moens, T.: Effects of cadmium on the fitness of, and interactions between, two bacterivorous nematode species, Appl. Soil Ecol., 56, 10-18, 2012.

McIntyre, A. D. and Warwick, R. M.: Methods for the Study of Marine Benthos (IBP Handbook), 2nd edn., vol. 16, Blackwell Science Ltd., Oxford, 1984.

Mirto, S., La Rosa, T., Danovaro, R., and Mazzola, A.: Microbial and meiofaunal response to intensive mussel-farm biodeposition in coastal sediments of the western Mediterranean, Mar. Pollut. Bull., 40, 244-252, 2000.

Modig, H. and Ólafsson, E.: Responses of Baltic benthic invertebrates to hypoxic events, J. Exp. Mar. Biol. Ecol., 229, 133-148, 1998.

Moodley, L., VanderZwaan, G. J., Herman, P. M. J., Kempers, L., and VanBreugel, P.: Differential response of benthic meiofauna to anoxia with special reference to Foraminifera (Protista: Sarcodina), Mar. Ecol.-Prog. Ser., 158, 151-163, 1997.

Moore, C. G. and Bett, B. J.: The use of meiofauna in marine pollution impact assessment, Zool. J. Linnean Soc., 96, 263-280, 1989.

Morigi, C. and Geslin, E.: Qualification of benthic foramniferal abundance, in: Methods for the Study of Deep-Sea Sediments, Their Functioning and Biodiversity, edited by: Danovaro, R., Taylor \& Francis, London, 2009.

Murray, J. W. and Bowser, S. S.: Mortality, protoplasm decay rate, and reliability of staining techniques to recognize "living" foraminifera: a review, J. Foramin. Res., 30, 66-70, doi:10.2113/0300066, 2000.

Murrell, M. C. and Fleeger, J. W.: Meiofauna abundance on the Gulf of Mexico continental shelf affected by hypoxia, Cont. Shelf Res., 9, 1049-1062, 1989.

Neira, C., Sellanes, J., Levin, L. A., and Arntz, W. E.: Meiofaunal distributions on the Peru margin: relationship to oxygen and organic matter availability, Deep-Sea Res. Pt. I, 48, 2453-2472, 2001.

Ott, J., Bright, M., and Bulgheresi, S.: Symbioses between marine nematodes and sulfur-oxidizing chemoautotrophic bacteria, Symbiosis, 36, 103-126, 2004.

Ott, J., Bright, M., and Bulgheresi, S.: Marine microbial thiotrophic ectosymbioses, in: Oceanography and Marine Biology: An An- nual Review, vol. 42, CRC Press, 95-118, 2005.

Peperzak, L. and Brussaard, C. P. D.: Flow cytometric applicability of fluorescent vitality probes on phytoplankton, J. Phycol., 47, 692-702, doi:10.1111/j.1529-8817.2011.00991.x, 2011.

Platt, H. M., Warwick, R. M., and Boucher, G.: Free-living marine nematodes. 1. British enoplids synopses of the British fauna (new series n-28), Cahiers Biol. Mar., 26, 125-126, 1985.

Pucci, F., Geslin, E., Barras, C., Morigi, C., Sabbatini, A., Negri, A., and Jorissen, F. J.: Survival of benthic foraminifera under hypoxic conditions: results of an experimental study using the CellTracker Green method, Mar. Pollut. Bull., 59, 336-351, 2009.

Rabalais, N. N., Díaz, R. J., Levin, L. A., Turner, R. E., Gilbert, D., and Zhang, J.: Dynamics and distribution of natural and humancaused hypoxia, Biogeosciences, 7, 585-619, doi:10.5194/bg-7585-2010, 2010.

Riedel, B., Zuschin, M., Haselmair, A., and Stachowitsch, M.: Oxygen depletion under glass: behavioural responses of benthic macrofauna to induced anoxia in the Northern Adriatic, J. Exp. Mar. Biol. Ecol., 367, 17-27, 2008.

Riedel, B., Zuschin, M., and Stachowitsch, M.: Tolerance of benthic macrofauna to hypoxia and anoxia in shallow coastal seas: a realistic scenario, Mar. Ecol.-Prog. Ser., 458, 39-52, doi:10.3354/meps09724, 2012.

Riedel, B., Pados, T., Pretterebner, K., Schiemer, L., Steckbauer, A., Haselmair, A., Zuschin, M., and Stachowitsch, M.: Effect of hypoxia and anoxia on invertebrate behaviour: ecological perspectives from species to community level, Biogeosciences, in preparation, 2013.

Soetaert, K. and Heip, C. H. R.: Nematode assemblages of deepsea and shelf break sites in the North Atlantic and Mediterranean Sea, Mar. Ecol.-Prog. Ser., 125, 171-183, 1995.

Sokal, R. R. and Rohlf, F. J.: Biometry, the Principles and Practice of Statistics in Biological Research, 3rd edn., W. H. Freeman and Company, New York, 1995.

Somerfield, P. J., Warwick, R. M., and Moens, T.: Meiofauna techniques, in: Methods for the Study of Marine Benthos, edited by: Eleftheriou, E. and McIntyre, A., Blackwell Science Ltd, Oxford, 229-272, 2005.

Stachowitsch, M.: Mass mortality in the Gulf of Trieste: the course of community destruction, Mar. Ecol., 5, 243-264, 1984.

Stachowitsch, M.: Anoxia in the northern Adriatic Sea: rapid death, slow recovery, in: Modern and Ancient Continental Shelf Anoxia, edited by: Tyson, R. V. and Pearson, T. H., Geological Society Special Publication Edn., vol. 58, The Geological Society, London, 119-129, 1991.

Stachowitsch, M., Riedel, B., Zuschin, M., and Machan, R.: Oxygen depletion and benthic mortalities: the first in situ experimental approach to documenting an elusive phenomenon, Limnol. Oceanogr.-Methods, 5, 344-352, 2007.

Steyaert, M., Moodley, L., Nadong, T., Moens, T., Soetaert, K., and Vincx, M.: Responses of intertidal nematodes to short-term anoxic events, J. Exp. Mar. Biol. Ecol., 345, 175-184, 2007.

Sutherland, T. F., Levings, C. D., Petersen, S. A., Poon, P., and Piercey, B.: The use of meiofauna as an indicator of benthic organic enrichment associated with salmonid aquaculture, Mar. Pollut. Bull., 54, 1249-1261, 2007.

Team, R. D. C.: R: A language and environment for statistical computing, available at: http://www.r-project.org, 2010. 
Thiel, H.: Qualitative Untersuchungen über die Meiofauna des Tiefseebodens, Sonerband, II, 131-148, 1966.

Tiemann, H. and Betz, K.-H.: Elutriation: theoretical considerations and methodological improvements, Mar. Ecol.-Prog. Ser., 1, 277-281, 1979.

Travisi, A.: Effect of anoxic stress on density and distribution of sediment meiofauna, Period. Biol., 102, 207-215, 2000.

Trejo-Chávez, H., García-Vilchis, D., Reynoso-Ducoing, O., and Ambrosio, J. R.: In vitro evaluation of the effects of cysticidal drugs in the Taenia crassiceps cysticerci ORF strain using the fluorescent CellTracker CMFDA, Exp. Parasitol., 127, 294-299, 2011.

Van Colen, C., Montserrat, F., Verbist, K., Vincx, M., Steyaert, M., Vanaverbeke, J., Herman, P. M. J., Degraer, S., and Ysebaert, T.: Tidal flat nematode responses to hypoxia and subsequent macrofauna-mediated alterations of sediment properties, Mar. Ecol.-Prog. Ser., 381, 189-197, doi:10.3354/meps07914, 2009.

Vaquer-Sunyer, R. and Duarte, C. M.: Sulfide exposure accelerates hypoxia-driven mortality, Limnol. Oceanogr., 55, 1075-1082, doi:10.4319/lo.2010.55.3.1075, 2010.

Veit-Köhler, G., Gerdes, D., Quiroga, E., Hebbeln, D., and Sellanes, J.: Metazoan meiofauna within the oxygen-minimum zone of Chile: results of the 2001-PUCK expedition, Deep-Sea Res. Pt. II, 56, 1105-1111, 2009.
Vernberg, W. B. and Coull, B. C.: Multiple factor effects of environmental parameters on the physiology, ecology and distribution of some marine meiofauna, Cahiers Biol. Mar., 16, 721-732, 1975.

Vopel, K., Dehmlow, J., Johansson, M., and Arlt, G.: Effects of anoxia and sulphide on populations of Cletocamptus confluens (Copepoda, Harpacticoida), Mar. Ecol.-Prog. Ser., 175, 121-128, doi:10.3354/meps 175121, 1998.

Vrišer, B.: Meiofaunal community structure and species diversity in the bays of Koper, Strunjan and Piran (Gulf of Trieste, North Adriatic), Nova Thalassia, 6, 5-17, 1984.

Walton, W. R.: Techniques for recognition of living foraminifera, Contrib. Cushman Found. Foramin. Res., 3, 56-60, 1952.

Wetzel, M. A., Fleeger, J. W., and Powers, S. P.: Effects of hypoxia and anoxia on meiofauna: A review with new data from the Gulf of Mexico, vol. 58, AGU, Washington, DC, doi:10.1029/CE058p0165, 2001.

Zhang, J., Gilbert, D., Gooday, A. J., Levin, L., Naqvi, S. W. A., Middelburg, J. J., Scranton, M., Ekau, W., Peña, A., Dewitte, B., Oguz, T., Monteiro, P. M. S., Urban, E., Rabalais, N. N., Ittekkot, V., Kemp, W. M., Ulloa, O., Elmgren, R., EscobarBriones, E., and Van der Plas, A. K.: Natural and human-induced hypoxia and consequences for coastal areas: synthesis and future development, Biogeosciences, 7, 1443-1467, doi:10.5194/bg-71443-2010, 2010. 